HStud 26 (2012)2, 189-204 DOI: 10.1556/HStud.26.2012.2.2

\title{
THE EFFECT OF THE UNIVERSITIES OF THE LOW COUNTRIES ON THE INTELLECTUAL HISTORY OF HUNGARY IN THE EARLY MODERN TIMES*
}

\author{
GÁBOR KECSKEMÉTI \\ Institute for Literary Studies, Research Centre for the Humanities, \\ Hungarian Academy of Sciences, Budapest \\ Hungary
}

\begin{abstract}
In the previous research, two periods were distinguished in the history of the intellectual connections between the Low Countries and Hungary in the early modern age. The first period, terminating at the beginning of the 17th century, was characterized with the impact of Renaissance Humanism, while in the second one, lasting from the 1620 s to the end of the century, Cartesian philosophy and Puritan theology were mentioned among the effects reaching Hungary. This paper deals with the traces of the intellectual and literary history of Hungary and Transylvania that can be connected to the extensive philological scholarship practiced at the universities of the Netherlands. The Hungarian crowd of students invading the university of Leiden from the end of the $1610 \mathrm{~s}$ - the university which was in the contemporary frontline of philological reflection and was also exceptional in the field of philological practice - faced the consequences of philological conceptions, especially of those permeated from Latin Humanism into the field of theology either gaining validity there or provoking intense discussion. This way, the effect of the Dutch Humanism did not decrease in this second period but - on the contrary - it just reached the zenith of its expansion and significance, being synthesized in a broader education programme.
\end{abstract}

Keywords: Leiden University, Hungarian students abroad, history of philology, school book transfer from Holland into Hungary

When about half a century ago, in 1961, Tibor Klaniczay for the first time systematically reviewed the history of the intellectual connections of the Low Countries and Hungary, he identified two periods of these relations. He characterized the first long period, terminating at the beginning of the 17th century, with the impact of Renaissance Humanism, while in the second one, lasting from the 1620 s to the end of the century, he emphasized the appeal and exemplary role of the Protestant model state of the Low Countries, and he mentioned the effect of Cartesian philos-

* This work was carried out as part of the TÁMOP-4.2.2/B-10/1-2010-0008 project in the framework of the New Hungarian Development Plan. The realization of this project is supported by the European Union, co-financed by the European Social Fund.

Hungarian Studies 26/2 (2012) 0236-6568/\$20.00 C 2012 Akadémiai Kiadó, Budapest 
ophy and Puritan theology among the ones reaching Hungary. He noted that researchers' attention was mostly concentrated on this period due to the that time mass university peregrination of students from Hungary and Transylvania, and to its extraordinary significance from the aspect of the intellectual history. ${ }^{1}$

Not many more examined the determinative role of the universities of the Low Countries in 17th-century Hungarian intellectual history with such exemplary richness in data and context as did Imre Bán in his monograph on János Apácai Csere published in $1958 .^{2}$ The sharp intellectual profile of the Puritan thinker influenced by both Cartesian and Ramist effects could only be drawn by considering those impacts and tendencies that affected him during his university studies in the Low Countries. What we can learn from Bán's book on the mid-17th-century intellectual map of the universities in Franeker, Leiden, Utrecht, and Harderwijk, is still a summary of the history of ideas having an orientating significance for Hungarian researchers. Only Dávid Csorba could recently draft a similarly wide panorama on those dynamically developing systems of philosophy, theology, pietism, philosophy of history, and political theory that determined the extremely multilateral intellectual life of the Low Countries. ${ }^{3}$ In the meantime, huge steps were taken in identifying the data and relations of university studies too; we do have hold of the so far most complete and creditable database of students from Hungary and Transylvania who studied at the universities of the Low Countries. ${ }^{4}$ Ferenc Postma and his colleagues did intense researches and published summaries on those printed dissertations of the universities of the Netherlands the respondent or sometimes even the author of which was a Hungarian or Transylvanian young man, significantly increasing the item numbers of the Hungarian retrospective bibliography. ${ }^{5}$ At the department of Netherlandistics in Debrecen, Réka Bozzay started to examine the institutional history of frequenting universities abroad, including the education-historical relations of the administration and the economics-historical relations of the travels, revealing and exploiting documents in the archives of both Hungary and the Netherlands. ${ }^{6}$ Furthermore, Péter Eredics masterfully managed to prove Andor Tarnai's nearly twenty-year-old suspicion too, ${ }^{7}$ showing in various case studies that in the literary works and literary thinking of students returning from the Low Countries not only foreign Latin university culture has an orientating and articulation marking significance, but also the texts of the mother-tongue and pietistic culture of the nation that hosts the students and makes home for the universities. ${ }^{8}$

Nevertheless, the other characteristic observed by Klaniczay is still alive: significantly less research targeted the period before young Hungarian theologians' streaming into the Netherlands; there is still little improvement in revealing the relations of the time in which the phenomena can be grouped around the 16th-century watchword of Renaissance Humanism and not around those later ones of Calvinist theology. Klaniczay himself tried to contribute to the connections history of 
this less examined period by calling the attention to Miklós Oláh's stay in the Low Countries and to his humanist relationships, and by discussing in detail the impact made by two humanists from the Low Countries on two Renaissance poets in Hungary: Janus Secundus' (1511-36) reception by Bálint Balassi and the partly ideological, partly stylistic - called mannerist by Klaniczay - effect of Justus Lipsius' (1547-1606) works made mainly on János Rimay and the circle of neo-Stoically thinking writers and thinkers in Rimay's environment. As for Lipsius, naturally his personal acquaintance to János Zsámboky (Sambucus) was also mentioned, and it was again Zsámboky whose connection with Hadrianus Junius (1511-75) was covered by Péter Eredics, several decades after Klaniczay's initiative study. ${ }^{9}$ Among those from the Low Countries who were less widely known but still had an impact in Hungary, Klaniczay mentioned Janus Dousa Sr.'s (1545-1604) humanist poetry, ${ }^{10}$ and he called the attention to Janus Gruterus (1560-1627) as well, but I suppose it is obvious that Gruterus' Hungarian connections and the history of his reception must be related first of all to the university of Heidelberg. ${ }^{11}$

Since then, basically only István Bitskey managed to add a larger number of new observations and conclusions to the facts recorded by Klaniczay. In an initiative study, he reviewed those humanists from the Low Countries who had been to 16th-century Hungary. ${ }^{12}$ Their protagonist is naturally Nicasius Ellebodius Casletanus (1535?-77), willingly examined by Klaniczay earlier, ${ }^{13}$ however in Bitskey's muster many more excellent men appear, several of whom - due to the nature of the phenomenon - have been to Hungary or Transylvania with missionary purposes as members of the Jesuit order.

Naturally, there is also an ever-growing amount of literature on the measurement of the extent and nature of the effects that can be connected to Lipsius' name. ${ }^{14}$ However, as the prevailment of his political theoretical and literary views is linked at least as much to the Catholic university in Leuven as to the Calvinist one in Leiden - and on top of that a little bit to the Lutheran one in Jena too - and as the thematizing effect of his problem raising is a Pan-European phenomenon, that is an orientating factor generally prevailing in intellectuals' discourse at the turn of the century, the confrontation with his works and thoughts can not be squeezed into the field of discussion of Dutch-Hungarian intellectual connections either in an effect-historical sense or in a connection-historical one. My own contribution to the completion of the history of Lipsius' reception in Hungary was calling the attention to the great extent to which Lipsius' German interpretations could influence the weekdays of studia humanitatis where - going straight against the authentic Lipsian aspirations - there could develop even its inclusion into the circle of Ramism and also its application that was in a unique syncretism with Ramism - offering a reception model even to Hungarian Puritanism. ${ }^{15}$ And as for Lipsius' philological activity - more precisely his Tacitus-edition dedicated 
partly to Zsámboky because of their professional relationship in Vienna ${ }^{16}$-, I recently claimed $^{17}$ that it was not made on the basis of the best manuscripts although those would have been available as well; and it only reaches the average classical philological standard of its age in documenting and exceeding the textual conditions of the used manuscripts and earlier editions: one can not decide when he presents someone else's conjecture, when his own and when the reading of a manuscript. ${ }^{18}$ It was so to say unavoidable for Lipsius' Tacitus-textology to become outworn in a philological sense right after the closure of his oeuvre. Naturally, these statements do not bring about a change regarding the fact that, from an aspect of the intellectual history, we still have to consider the Lipsian effect reaching Hungary at the turn of the 16th and 17th century to be of essential importance. ${ }^{19}$ At the same time, they call the attention to the point that those Hungarian Protestant intellectuals who, within the frameworks of religious orthodoxy, were alienating from Lipsius for confessional reasons - thinkers among whom there is for example Albert Szenci Molnár ${ }^{20}$ - did have room to move off from Lipsius not only in an ideological but also in a philological sense in the first third of the 17th century.

It seems that in the opening of the philological perspective following Lipsius, we have to attach a uniquely important role to the university of Leiden, the workshop that earlier, between 1578 and 1591 - before his returning to the Catholic church - used to have Lipsius himself as its leading philologist. ${ }^{21}$ It is another matter what philological perspectives could exactly open by the philological thinking of Leiden. ${ }^{22}$ Lipsius' successor in the professor of history's chair, Paulus Merula (1558-1607) as a philologist interpreted Ennius, Eutropius, and Paulus Diaconus. ${ }^{23}$ In his works, the modern history of universities and scholarship seizes and demonstrates such intellectual crisis phenomena that it considers partly expendable to the educational activity of Lipsius himself. The thesis statement that in Lipsius and Merula's time teaching Latin had a historical character in Leiden, ${ }^{24}$ does not simply sound innocent but it even has an acoustics of acknowledgement: it is obviously about a sign of epistemological stability and a kind of professionalisation that is corresponding to the needs and nature of philological discipline. However, the rise of Humanism to a higher scientific level inevitably goes hand in hand with the decline of its social function, that is professionalisation and marginalisation are parallel phenomena. ${ }^{25}$ For the marginalisation of the humanist philological project, simply professionalisation would provide a sufficient reason, but at the turn of the 16th and 17th century we can also see that the norms of humanist philological scholarship and the practical needs of the modern state move in two different, sharply receding directions, and there is hardly any connection between the humanist traditions of education and the need for professionals in the well-organised and properly governed state. ${ }^{26}$ In a methodological sense, the discrepancy can be described as a conflict of the pedagogical use of the 
commentary and the compendium. ${ }^{27}$ In the social history of the success of Ramist practicality in Central Europe, basically an alternative solution offered to the same dilemma or conflict is recognised by the new trend of research that has lifted the evaluation of Ramism out of the former, decades-old (medial) paradigm as late as in the beginning of the $2000 \mathrm{~s}$ and that is quite widely accepted today. ${ }^{28} \mathrm{Be}-$ cause Ramism is standing in the middle of this historical knowledge-sociological conflict, it sharply divides researchers even today, and sometimes it presents itself as the developer of a new, viable variety of humanist erudition, while at other times as the eliminator of the erudite world, and the rearer of an uneducated, technicist professional intelligentsia. ${ }^{29}$ The philologist Lipsius can by no means be suspected of giving a practical answer to this social and education-sociological challenge, what is more, with his famous statement claiming that no-one can be a great person who thinks that Ramus is a great person, he provided the decades-long resistance of conservative Humanism with the basic pattern of locking oneself up in elitism. ${ }^{30}$ The institute of Leiden for a long time stayed more or less on the track he had determined, that is in the model of the humanist elite university, but William Ames's chair, the university of Franeker became the centre of Ramism in the Low Countries from the $1620 \mathrm{~s} .{ }^{31}$ More than any other universities, young men from Hungary from that time on crowded the university of Franeker, where the number of Hungarian enrolments registered between the beginning of the 17 th and the end of the 18th century is nearly the double of the number in Leiden, ${ }^{32}$ which means that the practicality of the Franekerians was fully confirmed by the number of students. If the two kinds of role interpretation are in such a strong confrontation, then Tibor Klaniczay is completely right in saying that in the 1620 s a paradigm shift was happening in the relationship of Hungary and the Low Countries - in the field of the ideology after Dordrecht, confessional mass education fitting the immediate needs of Calvinism is taking over, with a science-theoretical regularity, from the period of Renaissance Humanism.

However, I do not mean to describe the situation with this exaggerated confrontation but rather create a horizon of questioning. That is, I am asking whether this was really the way it happened? Is the turn indicated by Klaniczay so unambiguously palpable?

The consequences relating to the faculty of humanities in Leiden seem to be undoubted, even already in Lipsius' decade as a teacher, thus these are basically synchronic with the existence of the university of Leiden: the minimal co-ordination between literary and philological education as the propaedeutic subjects of the faculty and the disciplines of professional specialization had an explicitly harmful impact on the humanist education of the future generation of theologians, lawyers and doctors, who wanted to complete the minimum level of philological studies in a few months so that they could be absorbed in their later profession and the studies providing them with a specialized knowledge as soon as possible. ${ }^{33}$ 
Lipsius himself could escape from the effect of these devastating processes because partly his Stoic moral philosophy and partly his thinking of political theory ensured him publicity and acknowledgement so his courses did not become deserted and low-grade. His successor, Merula was already deprived of the opportunities and premises of a similar culture-theoretical prevailment, thus we can not avoid naming the negative aspects of the crisis when talking about his activities as a professor: the autotelism of teaching Latin with a historical interest went hand in hand with students' disinterest and the neglect and hollowing of rhetorical and poetic studies. This tradition had a few followers at later times too at the university of Leiden (I am mentioning Johannes Meursius [1579-1639] and Petrus Cunaeus [1586-1638]) but it can not be called exclusive even at the end of the 16th century. ${ }^{34}$ In addition, the assembly of teachers, who represent the philological alternative, is very exceptional, and by the time we can talk about its mature version, that is the end of the $1610 \mathrm{~s}$, the students from Hungary arrive at the university as well.

The protagonist of the blood refreshment was Josephus Justus Scaliger (1540-1609) picked to be Lipsius' successor. ${ }^{35}$ As he had not accepted the first invitation, the history professor's place in Leiden was filled with Merula, however they did not give up convincing Scaliger, and since they offered very advantageous conditions to him - as a decus academiae he did not need to give public lectures at all - the famous Huguenot scholar finally moved to Leiden in 1593. Scaliger's views regarding the direct, practical use of studying Antique texts were quite different to Lipsius' ones: while adapting the information gained from readings to everyday life was a central element in Lipsius' political-theoretical conception (what is more, choosing the texts with prevailing commensurability and relevance), ${ }^{36}$ Scaliger denied this and confuted Lipsius' views who "neque est Politicus, nec potest quicquam in Politia: nihil possunt pedantes in illis rebus; nec ego nec alius doctus possemus scribere in Politicis". ${ }^{37}$ Scaliger at the same time surely for the respect he had for his father's poetics if for nothing else-overcame the non-productive collecting passion of the lexicological and antiquarian interest; he was a poet himself, a passionate researcher of Hellenistic poetry and of Persius, Juvenal, Ausonius, ${ }^{38}$ thus he realised the ambition of consummating the philological experiences in a literary production. ${ }^{39}$

All these facts testify the renewing of humanist Latin poetry of the Low Countries, which certainly has its importance in Hungary as well. János Rimay for example - as László Jankovits recently managed to virtuously prove it - was under the influence of Scaliger both when he took into consideration Scaliger's philological statements regarding Appendix Vergiliana and when he was planning a commentary on one of Scaliger's own poems. ${ }^{40}$ However, what is said so far is not yet suitable to refute the above detailed idea about theological students' quite 
widely observable disinterest in the new kinds of humanist aspirations. To shed light on this issue, we need further considerations.

First of all, we need to lay down that the above statement on the huge superiority of Hungarian enrolments in Franeker is not true for the first fifty years following 1620: at this time the number of Hungarian students is not the double of that in Leiden, it only exceeds that with one third. Nevertheless, it is more important that the majority of Hungarian enrolments is not registered at the faculties of humanities but - corresponding to the disciplinary and age related characteristics of university peregrination in all times - at the theological ones. Besides the 822 Hungarian students frequenting the theological faculties of the universities of the Low Countries, we only know about 63 enrolments made at the humanist faculties of the same universities in the five decades following $1620 .^{41}$ Based on the previous considerations, we could of course say that the students just rushing through philological studies could surely be issued with that devastating certificate which at all times goes to students hardly submerged in humanist education. But this is not really the way things are.

The fact that the examination of the texts of classical Antiquity with the tools of humanist philology is after all transformed into being of theological significance at the turn of the century in the Low Countries, can be clearly seen from the activities of Scaliger himself, above all from his chronologist activity that provided enough debate-provoking material for the confessional polemics extending to the whole 17 th century. ${ }^{42}$ But it is worth dealing with those students of Scaliger whose oeuvre and fate were developing before the careful eyes of Hungarian students studying in the Low Countries. I mention two of them now: Daniel Heinsius (1580-1655), a professor of poetry and later of Greek in Leiden, the librarian of the university after Merula's death, and his contemporary, Hugo Grotius (1583-1645) who is better known to us. Their career could not be any more differing; following the start their intellectual profile also developed very distinctly. After the synod of Dordrecht, Heinsius stayed on the orthodox side, ${ }^{43}$ while the remonstrant Grotius was imprisoned and after his release he could never set his foot on the ground of Leiden again. And the difference was demonstrated in their textological conception and philological practice too. In his remarks attached to the New Testament on the basis of Syrian texts, the fathers of the church, and the Septuaginta Heinsius emphasized as part of his principles that we must insist on the textus receptus which can only be amended in case of text corruption and based on differing text tradition, the text can not be changed incautiously, unwatchfully (temere) or ex ingenio that is on a conjectural basis. Grotius built his own philological views - which were also elaborated in the genre of annotations on much more radical grounds: he thought it possible that at certain places the original had not been kept by correct text variations and in such cases there is room for conjecture, furthermore the doctrine of inspiration was only related to 
the texts of the prophets and Christ, the rest was historical material in which the questions with less relevance might not even have had a generally expectable interpretation. All this was a slam dunk of course: when for the literal interpretation he was aspiring after a more systematic historical explanation, and doing this he loosened the typological connections as well, then according to his enemies he was judaizing, and when emphasizing the role of tradition he documented something referring to Antique and Patristic authors, then he was naturally accused of being papist. ${ }^{44}$ It is fairly visible from the differing philological conceptions of the two Scaliger-students in Leiden that the practice of philology not only gives room to the habitual layers of personality but it is also strongly connected to ideological orientation, it can partly reflect that and partly generate that too. ${ }^{45}$ And what can be drawn as a generally valid conclusion from the above: the principles, approaches, methodological processes of the philology of classical Antiquity are following Dordrecht the latest - surely not only insider secular issues for the members of a narrow humanist elite any more - some of whom could not even properly name their own religion as it was pretty well-known of the religiously indifferent Greek professor of Leiden, Bonaventura Vulcanius (1538-1614) ${ }^{46}$ - but they convert into the operations of the exegesis of the Bible requiring Latin, Greek, and Hebrew philological expertise and they turn into being the professionalism of Biblical philology. Imre Bán supposed that János Apácai Csere, who was interested in the philology of Eastern languages, was probably even a student of Heinsius in 1648 in Leiden, ${ }^{47}$ and furthermore it is a fact that in 1650 in Utrecht when he was just disputing in the topic of philologia sacra then the chairman of the dispute and author of the theses, Gisbertus Voetius (1589-1676) referred to both Heinsius' and Grotius' exegetic work. ${ }^{48}$ We meet at every step the philological relations of theological studies anyway around our students in the Low Countries. Johannes Leusden (1624-99) from Utrecht - with whom Apácai Csere was disputing in writing about the question of pronouncing God's name - offered to Mihály Apafi, the Prince of Transylvania a Hebrew philological compendium redacted at his students' request, ${ }^{49}$ and another one to Mihály Teleki, the chancellor. ${ }^{50}$ In 1661, Jakob Alting (1618-76) from Groningen sent two Hungarian students to Amsterdam, who were emerging with him in Hebrew language, in order to get a Jewish catechism for him. ${ }^{51}$ And István Técsi Joó, who was studying in Franeker and Leiden, published his methodological summary on the correct interpretation of texts - arranged in sixty points and with an origin not closely known in Hungary in a brochure of disputes from Várad (today Oradea in Romania) in $1647 .^{52}$

Needless to say that my intention with the above is primarily the indication of a task - of one which is related not so much to the professors but rather to their Hungarian audience. I simply find it unimaginable that the Hungarian crowd of students invading the university of Leiden from the end of the $1610 \mathrm{~s}$ - the university 
which was in the contemporary frontline of philological reflection and was also exceptional in the field of philological practice - did not take notice of the happenings going on before their eyes, often amid spectacular or fierce formalities. It is impossible that they could avoid facing the consequences of philological conceptions, especially because - as we have seen - those intruded to the field of theology as well either gaining validity there or provoking intense discussion. I suppose that systematically examining the oeuvre of our peregrines in Leiden, we will be able to collect the spectacular signs of taking philological and in some cases philological-theoretical positions. Let me only mention now that the first Hungarian translators of Erasmus', Lipsius', and Grotius' works have come from their group, namely György Salánki ${ }^{53}$ (1597-1641) and János Laskai ${ }^{54}$ (1605?-after 1657?); and the high quality of the Biblical philology of Rövid anatómia (Short Anatomy, 1630) by Péter Dengelegi Bíró (1597-1648), who was disputing with György Káldi, the translator of the Catholic Bible, has already very rightly aroused researchers' attention. ${ }^{55}$ But we can go further than that.

In September 1625, the state of Holland issued an order on the regulation of the education system of Latin schools,${ }^{56}$ which was actually not accepted by the other states of the Low Countries, in addition the implementation of its provisions was hindered in Holland itself because of its demanding content, however no similar measures regarding public education were published until $1815 .^{57}$ The idealistic and ambitious programme was elaborated by professors of Leiden, ${ }^{58}$ from whom we have to mention Cunaeus, Heinsius, and Gerardus Joannes Vossius (1577-1649) from the aspect of the subjects of studia humanitatis. ${ }^{59}$ In the course of regulating the subject materials of the six-grade education, Vossius' rhetorical summaries of various length were just as much specified as Scaliger or Heinsius' translations of Aphthonius and Theon. The educational specifications naturally created a great conjuncture in the market of school books in the Low Countries; the publishers of Leiden and Amsterdam contested for the publication of mandatory school books. These provisions explain for example the repeating publications of Vossius' rhetoric school books in the Low Countries.

The exigent school book programme of the state of the Low Countries had a very significant impact in Hungary and Transylvania. In 1651 in Gyulafehérvár (today Alba Iulia in Romania), a collection of Cicero's letters was published in Latin claiming on its front page that it was published "primum in usum scholarum Hollandiae et West Frisiae"60 just like the collection of Cicero's orations published a year later at the same place. ${ }^{61}$ Both text collections were the takeovers of two editions published in 1626 in Leiden. In 1685 in Lőcse (today Levoča in Slovakia), Terence was published "ex recensione Heinsiana". ${ }^{2}$ Both of the Hungarian editions, compiled on the basis of Joachim Fortius Ringelberg's (1499-1536) De ratione studii that is Comenius' print in Latin published in 1652 in Sárospatak and János Apácai Csere's version from Gyulafehérvár that was 
transformed into a conversation in Hungarian (1654), are based on the same source of Leiden published in 1622: the text of Scaliger's student, Thomas Erpenius (1584-1624) who was a professor of Arabic and Eastern languages from 1613 and second professor of Hebrew from $1619 .{ }^{63}$ Both the Latin editions of the Heidelberg Catechism amended with didactic supplementary material, published in Várad in 1652 and in Szeben (today Sibiu in Romania) in 1666 are the results of this school book programme, and this version was the basis of the Hungarian-language editions of 1650 in Amsterdam and of 1652 in Várad, the latter ones being the basics and samples for most Hungarian editions of the Catechism until $1870 .^{64}$ The Holland provision meant the Sulpitius Severus-Johannes Sleidanus edition, issued in Kolozsvár (today Cluj Napoca in Romania) in 1701 at Miklós Tótfalusi Kis's, ${ }^{65}$ to be used for teaching history. The same printing-house produced the Transylvanian adaptation of Vossius' rhetoric school book in $1696 .{ }^{66}$

It is hard to overestimate the importance of the long list of these school book editions. Following the meetings with the philologists of Leiden, there were born not only the Hungarian university students' high-standard works that express high-level individual aspirations and should be listed one by one, but the same humanists of Leiden with their school books made an essential and long-lasting impact on both Hungary's rhetorical and historical education in Latin and its theological education in vernacular language. And as from these books not only those were received in Hungary which represented a Calvinist conception of religion and historical philosophy, but also those which were destined to form the basic Latin qualifications and competence of studia humanitatis, we think it is absolutely necessary to somewhat weaken the divider line between the two eras set to approximately 1620 by earlier researches. It is necessary to warn that in the decades when Calvinist theological peregrination in the Netherlands became multitudinous, the Hungarian effect of the Humanism in the Low Countries did not decrease but - on the contrary - it just reached the zenith of its expansion and significance as a substance of erudition being synthesized in a broader education programme.

\section{Notes}

1 Klaniczay, Tibor (1973) ‘A németalföldi humanizmus és a magyar reneszánsz költészet’ (Humanism in the Netherlands and Renaissance poetry in Hungary) in Tibor Klaniczay $A$ múlt nagy korszakai (Great periods of the past) (Budapest: Szépirodalmi Könyvkiadó), 211-25, 484-5.

2 Bán, Imre (1958) Apáczai Csere János (Budapest: Akadémiai Kiadó - extended edition 2003) Irodalomtörténeti Könyvtár 2.

3 Csorba, Dávid (2010) “A történelem, ahogy Hollandiában írták, avagy a 17. századi hollandiai történelem-képzetek magyar recepciója’ (History as written in the Netherlands, or Hungarian 
reception of the concepts on history in 17th century Low Countries), in Gábor Pusztai and Réka Bozzay (2010) (eds) Debrecentöl Amszterdamig: Magyarország és Németalföld kapcsolata (From Debrecen to Amsterdam: Connections between Hungary and the Netherlands) (Debrecen: Debreceni Egyetem BTK, Néderlandisztika Tanszék), 251-72.

4 Bozzay, Réka and Ladányi, Sándor (2007) Magyarországi diákok holland egyetemeken 1595-1918 (Hungarian students at universities in the Netherlands) (Budapest: ELTE Levéltára) Magyarországi Diákok Egyetemjárása az Újkorban 15. The first Hungarian enrolments are preceded by Imre Újfalvi's stay in Leiden with two decades; on his connections in the Low Countries see Keserü, Bálint (1969) 'Újfalvi Imre és az európai «későhumanista ellenzék»' (Imre Újfalvi and the European "late humanist opposition") Acta Historiae Litterarum Hungaricarum, Vol. 9, 3-46, 19-33.

5 Postma, Ferenc (1997) 'Franeckera, az igaz keresztyéneknek híres akadémiájuk benne' (The famous academy of true Christians in Franeker) in Mihály Balázs et al. (eds) Müvelödési törekvések a korai újkorban: Tanulmányok Keserü Bálint tiszteletére (Cultural efforts in the early modern period: Studies in honour of Bálint Keserü) (Szeged) Adattár 35, 487-95; Postma, Ferenc 'Magyarok és a franekeri egyetemi oktatás' (Hungarians and the university teaching in Franeker) in Pusztai-Bozzay Debrecentöl Amszterdamig..., op. cit., 113-56; Postma, Ferenc and P. Vásárhelyi, Judit (2011) 'István Geleji Katona der Jüngere und seine drei ungarischsprachigen Gedichte aus dem Jahre 1654' in Gábor Kecskeméti and Réka Tasi (eds) Bibliotheca et Universitas: Tanulmányok a hatvanéves Heltai János tiszteletére (Studies in honour of János Heltai) (Miskolc: Miskolci Egyetem BTK, Magyar Nyelv- és Irodalomtudományi Intézet), 273-84.

6 Bozzay, Réka (2002) 'Debreceni diákok a leideni egyetemen a XVII. században’ (Students from Debrecen in Leiden University in the 17th century) Debreceni Szemle, Vol. 10, 307-16; Bozzay, Réka (2009) Die Peregrination ungarländischer Studenten an der Universität Leiden, 1595-1796 (Budapest: MTA Egyetemtörténeti Albizottság-ELTE Levéltár) Felsőoktatástörténeti Kiadványok 8; Bozzay, Réka 'Magyar diákok leideni peregrinációjának előzményei a 17-18. században' (Hungarian students in Leiden in the 17-18th centuries: Events before their travels) in Pusztai-Bozzay, Debrecentöl Amszterdamig..., op. cit., 89-111; Bozzay, Réka (2011) 'A harderwijki egyetem jelentősége a kora újkori magyar peregrináció történetében’ (The importance of Harderwijk University in the history of early modern Hungarian study trips) in Mihály Imre et al. (eds) Eruditio, virtus et constantia: Tanulmányok a 70 éves Bitskey István tiszteletére (Studies in honour of István Bitskey) (Debrecen: Debreceni Egyetemi Kiadó), I, 357-363.

7 Tarnai, Andor (1994) 'A váradi Orator extemporaneus' (The Orator extemporaneus of Várad), in József Jankovics (ed.) Klaniczay-emlékkönyv: Tanulmányok Klaniczay Tibor emlékezetére (Studies to the memory of Tibor Klaniczay) (Budapest: Balassi Kiadó), 365-78, 373.

8 Eredics, Péter (2008) Ungarische Studenten und ihre Übersetzungen aus dem Niederländischen ins Ungarische in der Frühen Neuzeit (Frankfurt a. Main: Peter Lang Verlag) Debrecener Studien zur Literatur 14; Eredics, Péter 'Ifj. Buzinkai György elfeledett holland fordítása a 18. századból' (György Buzinkai, Jr.'s forgotten translation from Dutch in the 18th century) in Pusztai-Bozzay Debrecentöl Amszterdamig ..., op. cit., 185-207.

9 Eredics, Péter (1998) 'Joannes Sambucus és Hadrianus Junius' (Joannes Sambucus and Hadrianus Junius) in László Jankovits and Gábor Kecskeméti (eds) Janus Pannonius és a humanista irodalmi hagyomány (Janus Pannonius and the humanist literary tradition) (Pécs: JPTE), 89-96.

10 In his famous letter written to Lipsius, Rimay sent his greetings to Dousa as well among others, see Rimay, János (1955) Összes müvei (The complete works of János Rimay) ed. Sándor 
Eckhardt (Budapest: Akadémiai Kiadó), 226; Rimay, János (1992) Írásai (Collected writings) ed. Pál Ács (Budapest: Balassi Kiadó) Régi Magyar Könyvtár: Források 1, 210.

11 Cf. Kecskeméti, Gábor 'Filiczky János (csaknem) ismeretlen köszöntőverse' (An [almost] unknown greeting poem by János Filiczky) in Kecskeméti-Tasi Bibliotheca et Universitas ..., op. cit., $149-56$.

12 Bitskey, István 'Németalföldi humanisták a 16. századi Magyarországon’ (Humanists from the Netherlands in Hungary in the 16th century) in Pusztai-Bozzay Debrecentöl Amszterdamig..., op. cit., 45-57.

13 Klaniczay, Tibor (1971) 'Nicasius Ellebodius és poétikája' (Nicasius Ellebodius and his poetics) Irodalomtörténeti Közlemények, Vol. 75, 24-34.

14 See recently: Bene, Sándor (2012) 'Rimay vindicatus (Rimay János Justus Lipsiushoz írott leveléről)' (On János Rimay’s letter written to Justus Lipsius) in Gábor Kecskeméti and Réka Tasi (eds) Filológia és textológia a régi magyar irodalomban: Tudományos konferencia, Miskolc, 2011. május 25-28 (Philology and textology in the old Hungarian literature) (Miskolc: Miskolci Egyetem BTK Magyar Nyelv- és Irodalomtudományi Intézet), 139-88.

15 Kecskeméti, Gábor (2007) „A böcsületre kihaladott ékes és mesterséges szóllás, írás”: A magyarországi retorikai hagyomány a 16-17. század fordulóján (Rhetorical tradition in Hungary at the turn of the 16th-17th centuries) (Budapest: Universitas Kiadó) Irodalomtudomány és Kritika: Tanulmányok, 351-61.

16 More precisely: we are talking about eight editions at least, including the first one in 1574 and the posthumous one in 1607.

17 Kecskeméti, Gábor (2010) 'Tacitus és a régi magyar irodalom' (Tacitus and the old Hungarian literature) Irodalomtörténeti Közlemények, Vol. 114, 430-8. More important from the literature cited there: Brink, C. O. (1951) 'Justus Lipsius and the Text of Tacitus' The Journal of Roman Studies, Vol. 41, Nos 1-2, 32-51.

18 D'Amico, John F. (1988) Theory and Practice in Renaissance Textual Criticism: Beatus Rhenanus between Conjecture and History (Berkeley etc.: University of California Press), 112-26; cf. E[dward] J[ohn] Kenney (1974) The Classical Text: Aspects of Editing in the Age of the Printed Book (Berkeley etc.: University of California Press) Sather Classical Lectures 44, 53-4.

19 Researches indeed warn us that Lipsius' intention was not closely philological either. See more recently: Papy, Jan (2005) 'Les points de vue d'Érasme et de Lipse sur la philologie : continuité ou rupture ?' in Perrine Galand-Hallyn, Fernand Hallyn and Gilbert Tournoy (eds) La philologie humaniste et ses représentations dans la théorie et dans la fiction (Genève) Romanica Gandensia 32, II, 599-620. (The author gives a definite answer to the question in the title: he emphasizes the continuity between Erasmus and Lipsius, the similarity of their philological principles, and rather the moral orientation of their text publications than the textological one.) On the effect of the Polybian principle of similitudo temporum and on Lipsius' conception of monumenta-monimenta following Varro and Seneca: Papy, Jan (2004) 'An Antiquarian Scholar between Text and Image? Justus Lipsius, Humanist Education, and the Visualization of Ancient Rome' The Sixteenth Century Journal, Vol. 35, No. 1, 97-131.

20 Turóczi-Trostler, József (1955) 'Szenczi Molnár Albert Heidelbergben’ (Albert Szenczi Molnár in Heidelberg) Filológiai Közlöny, Vol. 1, 9-18, 139-62; idem in József TurócziTrostler (1961) Magyar irodalom - világirodalom: Tanulmányok (Hungarian literature world literature: Studies) (Budapest: Akadémiai Kiadó), II, 109-55, 722-7.

21 On Lipsius' professorship in Leiden, with a detailed presentation of the intellectual and confessional changes during the decade he spent there: De Landtsheer, Jeanine (2011) 'Pius Lipsius or Lipsius Proteus?' in Jeanine De Landtsheer and Henk Nellen (eds) Between Scylla and Charybdis: Learned Letter Writers Navigating the Reefs of Religious and Political Con- 
troversy in Early Modern Europe (Leiden etc.: Brill) Brill's Studies in Intellectual History 192, 303-49.

22 To the following, with more data and in a different context, see my study: Kecskeméti, Gábor 'A humanista filológiai hagyomány és Magyarország' (The humanist philological tradition and Hungary) in Kecskeméti-Tasi Filológia és textológia ..., op. cit., 13-51.

23 Meter, Jan Hendrik (1984) The Literary Theories of Daniel Heinsius: A Study of the Development and Background of His Views on Literary Theory and Criticism during the Period from 1602 to 1612 (Assen: Van Gorcum) Respublica literaria Neerlandica 6, 17.

24 Ibid., 25.

25 Ibid., 16-17.

26 Ibid., 16-17. The ideas preparing the establishment of the Leiden university univocally defined a training of experts with attention to practicality; see Otterspeer, Willem (2001) 'The University of Leiden: An Eclectic Institution' Early Science and Medicine, Vol. 6, No. 4, 324-33, 324-5.

27 In practice, this could mean the use of the first of them in the public courses, while that of the more practical other in the private courses. See Ibid., 328-9.

28 Hotson, Howard (2007) Commonplace Learning: Ramism and Its German Ramifications, 1543-1630 (Oxford etc.: Oxford University Press). The creator of the earlier medial trend, heavily criticized by Hotson, was (naturally) father Ong's narration that seemed very new in its own time and is still quoted in Hungary without suspicion: Ong, Walter J[ackson] (1959) Ramus: Method, and the Decay of Dialogue: From the Art of Discourse to the Art of Reason (Cambridge, MA: Harvard University Press).

29 These can be indicated as two extreme standpoints: Grafton, Anthony and Jardine, Lisa (1986) From Humanism to the Humanities: Education and the Liberal Arts in Fifteenth and Sixteenth Century Europe (Cambridge, MA: Harvard University Press); Tracy, James D. (1990) 'From Humanism to the Humanities: A Critique of Grafton and Jardine' Modern Language Quarterly, Vol. 51, No. 2, 122-43, 139-40.

30 Kecskeméti “A böcsületre kihaladott...”, op. cit., 350; Otterspeer 'The University of...' op. cit., 328.

31 On the system of technometria, the Ramist theory of knowledge established by him: Sprunger, Keith L. (1968) 'Technometria: A Prologue to Puritan Theology' Journal of the History of Ideas, Vol. 29, No. 1, 115-22; Gibbs, Lee W. (1972) 'William Ames's Technometry' Journal of the History of Ideas, Vol. 33, No. 4, 615-24.

32 Bozzay-Ladányi Magyarországi diákok holland..., op. cit., 19.

33 Meter The Literary Theories..., op. cit., 17. Registration numbers clearly show the process. In the first two and a half decades of the existence of the Leiden university, 53\% of students enrolled in the courses of the faculty of humanities while between 1650 and 1674 this was only $35 \%$ while the number of students frequenting the faculty of law increased slightly and the number of students at the faculty of medicine rose steeply. Most doctoral degrees were assigned to students of law (above $50 \%$ all the time in the first hundred years) and of medicine (around $40 \%$ ) while doctors of philosophy stood at 3\%. See more: Otterspeer, 'The University of...' op. cit., 331.

34 Meter The Literary Theories..., op. cit., 25.

35 Pfeiffer, Rudolf (1976) History of Classical Scholarship from 1300 to 1850 (Oxford: Clarendon Press), 113-19. Lipsius' succession in Leiden was much smoother than later, after his death the one in Leuven where the successor's enemies would have been happier even with a Heinsius or a Grotius than with Erycius Puteanus; see Verbeke, Demmy (2009) ' "Condemned by Some, Read by All»: The Attempt to Suppress the Publications of the Louvain Humanist 
Erycius Puteanus in $1608^{\prime}$ Renaissance Studies: Journal of the Society for Renaissance Studies, Vol. 24, No. 3, 353-64, 355.

36 Anthony Grafton (1985) 'Renaissance Readers and Ancient Texts: Comments on Some Commentaries' Renaissance Quarterly, Vol. 38, 615-49, 639.

37 Ibid., 620. However, Grafton demonstrates at the same place that in practice - for instance in his Caesar-edition from 1606 - Scaliger does not assert his own radically sharpened ideas with consistent regularity.

Meter The Literary Theories..., op. cit., 18. To the evaluation of his Ausonius-edition: Schoeck, Richard J. (1988) 'On the Editing of Classical Texts before Vinet: Early Printed Editions of Ausonius before 1580' in Stella Purce Revard, Fidel Rädle and Mario A. Di Cesare (eds) Acta conventus neo-Latini Guelpherbytani: Proceedings of the Sixth International Congress of Neo-Latin Studies, Wolfenbüttel 12 August to 16 August 1985 (Binghamton NY: Center for Medieval and Early Renaissance Studies), Medieval and Renaissance Texts and Studies $53,137-44$.

39 Grafton 'Renaissance Readers...', op. cit., 643. The placement of Lipsius' Menippean satire in a similar framework, namely in the context of the Petronius-philology: Grafton, Anthony (1990) 'Petronius and Neo-Latin Satire: The Reception of the Cena Trimalchionis' Journal of the Warburg and Courtauld Institutes, Vol. 53, 237-49, 243. We have to note that according to Ronald G. Witt the aspiration to imitate classical Latin style is the sine qua non of Humanism without which we can not talk about Humanism, only about antiquarianism - however others articulate their wider conception of Humanism as opposed to this view, cf. Black, Robert (2006) 'The Origins of Humanism' in Angelo Mazzocco (ed.) Interpretations of Renaissance Humanism (Leiden etc.: Brill) Brill's Studies in Intellectual History 143, 37-71, 38.

40 According to the former one, Scaliger's version of the Appendix should be taken into account as an edition publishing the imitation patterns of Örülhetne szivem... (My heart could be happy...) and the Lydia-poems, see Jankovits, László (2011) 'Rimay János: Örülhetne szivem...' (János Rimay: My heart could be happy...) Irodalomtörténeti Közlemények, Vol. $115,246-55$. To the latter one see ibid., 250, providing a solution in the 40th piece of Iambi gnomici for the Latin inlay - searched in vain so far - of a letter by Rimay evaluating András Prágai's work as a translator. The popularity of this poem collection can not be doubted: in the database of inscriptions in alba amicorum of Hungarian owners, presently five pieces of data prove its use in the 17th and 18th centuries by both Hungarian and foreign registrars (the five notes only refer to two pieces of the collection), see Inscriptiones alborum amicorum, ed. Miklós Latzkovits, http://iaa.bibl.u-szeged.hu (27.08.2012).

41 Bozzay-Ladányi Magyarországi diákok holland..., op. cit., 22.

42 On Scaliger's activity as chronologist see Grafton, Anthony T. (1975) 'Joseph Scaliger and Historical Chronology: The Rise and Fall of a Discipline' History and Theory, Vol. 14, No. 2, $156-85$.

43 On his conception of religion and church politics in detail: Sellin, Paul R. (1968) 'Puritan and Anglican: A Dutch Perspective' Studies in Philology, Vol. 65, No. 5, 804-15.

44 Jan Bloemendal and Henk Nellen (2009) 'Early Enlightenment or High Philology? Biblical Textual Criticism and Exegesis by Two Famous Alumni of Leiden University, Daniel Heinsius and Hugo Grotius' in Gertraud Mitterauer et al. (eds) Was ist Textkritik? Zur Geschichte und Relevanz eines Zentralbegriffs der Editionswissenschaft (Tübingen: Max Niemeyer Verlag) Beihefte zu Editio 28, 113-28. Against Grotius' Bible-interpretations there were Lutheran debates going on for long years - mainly in Wittenberg - in which Hungarian students were involved as well. See among others: Szabó, Károly (1879-1898) Régi magyar könyvtár (Budapest: MTA; hereafter: RMK), III, nos 2308, 2406, 2458, 2607, 6403. 
45 This time we are not mentioning those obvious cases when complete philological projects are implemented with the aim of confessional confrontation, just like Isaac Casaubon implements the philological examination of the dating and attribution of Corpus Hermeticum with the aim of discrediting Cesare Baronio's church history; see Anthony Grafton (1983) 'Protestant versus Prophet: Isaac Casaubon on Hermes Trismegistus' Journal of the Warburg and Courtauld Institutes, Vol. 46, 78-93. - An interesting attempt to study the confessionalization exposure of respublica litteraria demonstrating the difference between the situations in Leiden and in Paris with the proportions of confessional distribution of Scaliger's and Casaubon's correspondence: Van Miert, Dirk 'The Limits of Transconfessional Contact in the Republic of Letters around 1600: Scaliger, Casaubon, and Their Catholic Correspondents' in De LandtsheerNellen, Between Scylla and..., op. cit., 367-408.

46 Because of this it was not an easy task to bury the Greek professor either: if the pietas could not be mentioned, in his funeral oration the young professor of politics, Cunaeus had to turn to mentioning not only Scaliger but even Lipsius, who was considered an enrager, as the ones with whom Vulcanius is now enjoying the joys of erudition in the other world; see Heesakkers, Chris L. (1994) 'De mortuis non nisi bene? The Leiden Neo-Latin Funeral Oration' in Rhoda Schnur (general ed.) Acta conventus neo-Latini Hafniensis: Proceedings of the Eighth International Congress of Neo-Latin Studies, Copenhagen, 12 August to 17 August 1991 (Binghamton, NY: Center for Medieval and Early Renaissance Studies) Medieval and Renaissance Texts and Studies 120, 219-29, 227-8.

47 Bán Apáczai Csere János, op. cit., 97.

$48 \quad$ Ibid., 129, 131.

49 Goldziher, Ignác (1883) 'A keleti tanulmányok történetéhez hazánkban a XVII. században' (To the history of the Eastern studies in Hungary in the 17th century) Egyetemes Philologiai Közlöny, Vol. 7, 42-4.

50 Goldziher, Ignác (1884) 'Teleki Mihály erdélyi kanczellár és Leusden János utrechti tanár' (Mihály Teleki chancellor of Transylvania and the Utrecht professor Johann Leusden) Egyetemes Philologiai Közlöny, Vol. 8, 666-7.

51 Marmorstein, Arthur (1914) 'Magyar hebraisták' (Hungarian Hebraists) Magyar Könyvszemle, Vol. 22, 194-5.

52 Régi magyarországi nyomtatványok (1971-2012) (Budapest: Akadémiai Kiadó; hereafter: RMNy), no. 2200.

53 Klaniczay, Tibor (1985) 'Egy epizód Erasmus utókorából: a magyar Enchiridion (1627)’ (An episode from the posterity of Erasmus: the Hungarian Enchiridion) in Tibor Klaniczay Pallas magyar ivadékai (Hungarian seed of Pallas) (Budapest: Szépirodalmi Könyvkiadó), 129-37.

54 Laskai, János (1970) Válogatott müvei: Magyar Iustus Lipsius (Selected works of János Laskai: Hungarian Justus Lipsius), ed. Márton Tarnóc (Budapest: Akadémiai Kiadó) Régi Magyar Prózai Emlékek 2 .

55 Koncz, Attila (2000) 'Hitvitázó tudomány vagy tudományos hitvita? (Káldi György és Dengelegi Péter polémiája)' (Polemics between György Káldi and Péter Dengelegi) Irodalomtörténeti Közlemények, Vol. 104, 669-94.

56 Land, J. P. N. (1878) 'Philosophy in the Dutch Universities' Mind, Vol. 3, No. 9, 87-104, 92. The regulation of the material of schola puerilis in reality cured the problems emerging because of the lack of organising the university after modus parisiensis; see Otterspeer 'The University of...', op. cit., 327.

57 On the new educational provisions, which confronted the tradition of the educational practice of the 17-18th centuries with the requirements of the 19th century, and on the less joyful experiences of their implementation see in detail Land 'Philosophy...', op. cit. 
58 The primary guideline of the below exposition: Spies, Marijke (1995) 'Amsterdam Schoolorations from the Second Half of the Seventeenth Century' Lias, Vol. 22, 99-118; idem in Marijke Spies (1999) Rhetoric, Rhetoricians and Poets: Studies in Renaissance Poetry and Poetics (Amsterdam: Amsterdam University Press), 79-91, 152-3.

59 After Dordrecht, Heinsius' and Grotius' fellow student, Vossius was also removed from the regent post of the Leiden academy, he could only return in 1622, and even then not as a theologian but as the rhetoric professor of the university. It is not by chance that he kept his friendship with Grotius until his death while with Heinsius only until about 1627; cf. Rademaker, C. S. M. (1981) Life and Work of Gerardus Joannes Vossius (1577-1649) (Assen: Van Gorcum) Respublica literaria Neerlandica 5, 155-6. Obviously, the relation between Heinsius and Vossius was further impaired by the intimate relationships the latter one had in Laudian England; cf. Sellin 'Puritan and Anglican...' op. cit., 811. It was also due to the remonstrant sympathies that Vossius developed a classification which was remarkably different to Amesius' Ramist scientific taxonomy; cf. Sellin, Paul R. (1991) 'The Seventeenth-century Taxonomy of Arts and Sciences' in G. J. Vossius's De artium et scientiarum natura and John Milton's 'Curriculum' in Of Education' in Alexander Dalzell, Charles Fantazzi and Richard J. Schoeck (eds) Acta conventus neo-Latini Torontonensis: Proceedings of the Seventh International Congress of Neo-Latin Studies, Toronto, 8-13 August 1988 (Binghamton, NY: Center for Medieval and Early Renaissance Studies) Medieval and Renaissance Texts and Studies 86, 655-64.

60 RMNy, no. 2367.

61 RMNy, no. 2416.

62 RMK, II, no. 1572.

63 RMNy, nos. 2436, 2516. On Erpenius: Bruehl, Clemens M. (1960, 1961) 'Josef Justus Scaliger: Ein Beitrag zur geistesgeschichtlichen Bedeutung der Altertumswissenschaft' Zeitschrift für Religions- und Geistesgeschichte, Vol. 12, 201-18; Vol. 13, 45-65, 218, 63; the wider context is explained in the whole study, tracing back Scaliger's strong interest in Hebrewistics to the studies he had with Guillaume Postel.

64 RMNy, nos. 2452, 3318, 2304, 2457. The editions of Várad and Szeben were printed by Ábrahám Szenci Kertész. Research suggested that János Apácai Csere and György Komáromi Csipkés could also have to do with the Hungarian translation: Nagy, Barna (1965) 'A Heidelbergi Káté jelentkezése, története és kiadásai Magyarországon a XVI. és XVII. században' (The history and editions of Heidelberg Catechism in Hungary in the 16th and 17th centuries) in Tibor Bartha (ed.) A Heidelbergi Káté története Magyarországon (The history of the Heidelberg Catechism in Hungary) (Budapest: Magyarországi Református Egyház Zsinati Irodájának Sajtóosztálya) Studia et Acta Ecclesiastica 1, 17-91, 51-62.

65 RMK, II, no. 2066.

66 RMK, II, no. 1832. See on this Tarnai, Andor (1985) 'G. J. Vossius retorikájának kolozsvári kiadásai' (Kolozsvár editions of the rhetoric by G. J. Vossius) in Szabolcsné Gomba and György Haiman (eds) Tótfalusi Kis Miklós: Elöadások (Papers on Miklós Tótfalusi Kis) (Debrecen: KLTE Könyvtára), 151-7. It is very likely - although the front page does not indicate it in opposition to the ones listed so far - that the idea of the Várad edition of the rhetoric by Radau in 1656 (RMNy, no. 2684) also originated from the practice of the implementation of the pedagogical programme in the Low Countries. On the latter school book: Tarnai 'A váradi Orator...' op. cit. 